\title{
Intimacy, Zoom Tango and the COVID-19 Pandemic
}

\section{Jonathan Skinner}

\begin{abstract}
Aвstract: This is a personal reflection reacting and responding to the COVID-19 global pandemic and the domestication and on-lining of physical leisure pursuit. In Anthony Giddens' The Transformation of Intimacy, there is the suggestion that the condition of the plastic is one 'decentred' and 'freed from the needs of reproduction'. Giddens was writing generally about sexuality and the physical labour of reproduction, but this suggestion warrants wider exploration, particularly when Giddens concludes his argument with the suggestion that intimacy and democracy are ideally implicated in each other: autonomy of the self and open conditions of association as preconditions for establishing his reflexive project of the self. This personal reflection develops this suggestion by looking at two creative responses to the pandemic lockdown as socially distanced tennis and Zoom tango become tactics for living with the unexpected, for coping with isolation, for retaining and returning to an everyday.
\end{abstract}

KeYwords: COVID-19, Giddens, intimacy, tango, tennis, Zoom
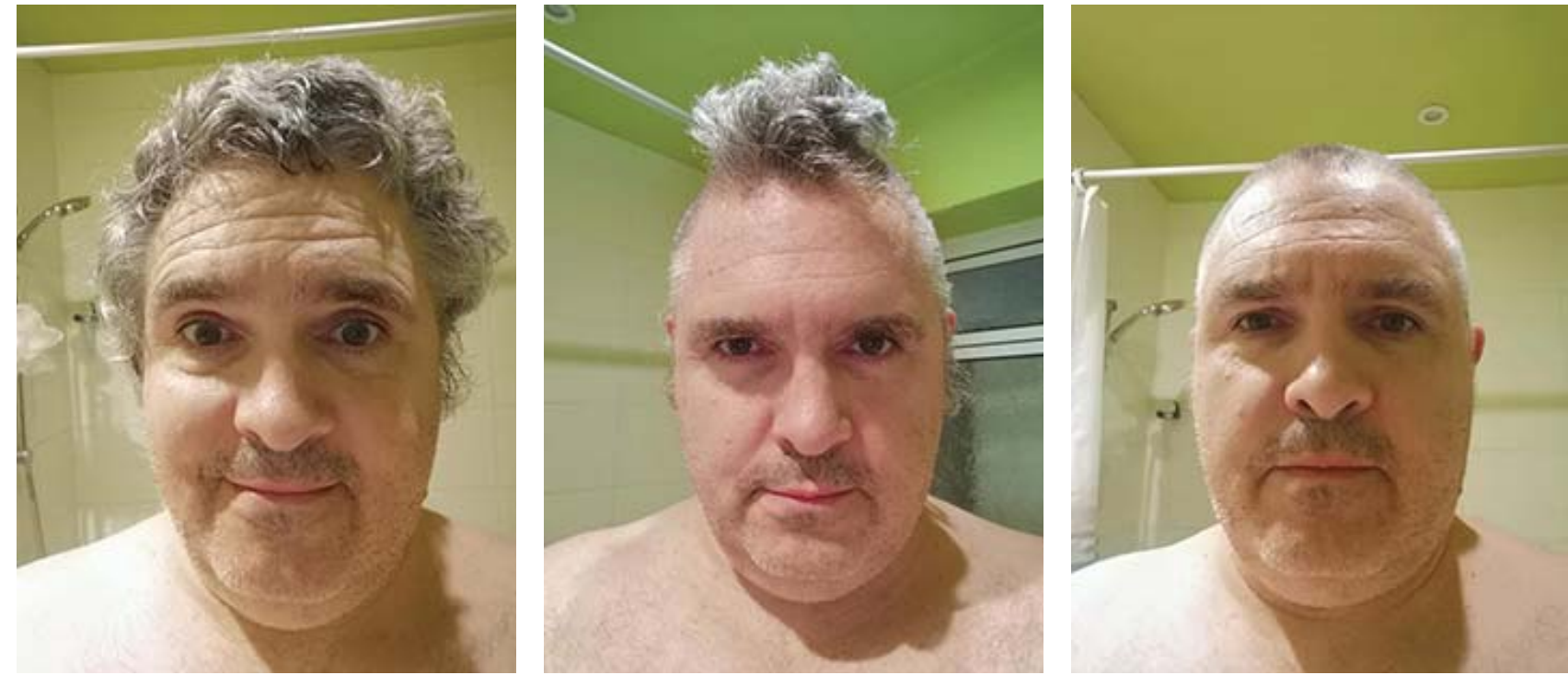

Figures 1a, 1b, and 1c. Triptych - The Changing Face of the Pandemic. Photos courtesy of the author.

I write. I dance. I parent. I do all this in lockdown with my wife and with a two-month-old unregistered and unseen boy we have called Casian. Each day, I roll him through the neighbourhood, avoiding anyone walking towards us. I cross the road, or they cross the road (Figure 2). A softer position is to take to the road whilst we pass on the pavement. I curse those that do not give us space. I laugh inside at the

Anthropology in Action, 27, no. 2 (Summer 2020): 87-92 (C) Berghahn Books and the Association for Anthropology in Action ISSN 0967-201X (Print) ISSN 1752-2285 (Online) doi:10.3167/aia.2020.270214

This article is distributed under the terms of the Creative Commons Attribution Noncommercial No Derivatives 4.0 International license (https://creativecommons.org/licenses/by-nc-nd/4.0/). For uses beyond those covered in the license contact Berghahn Books. 


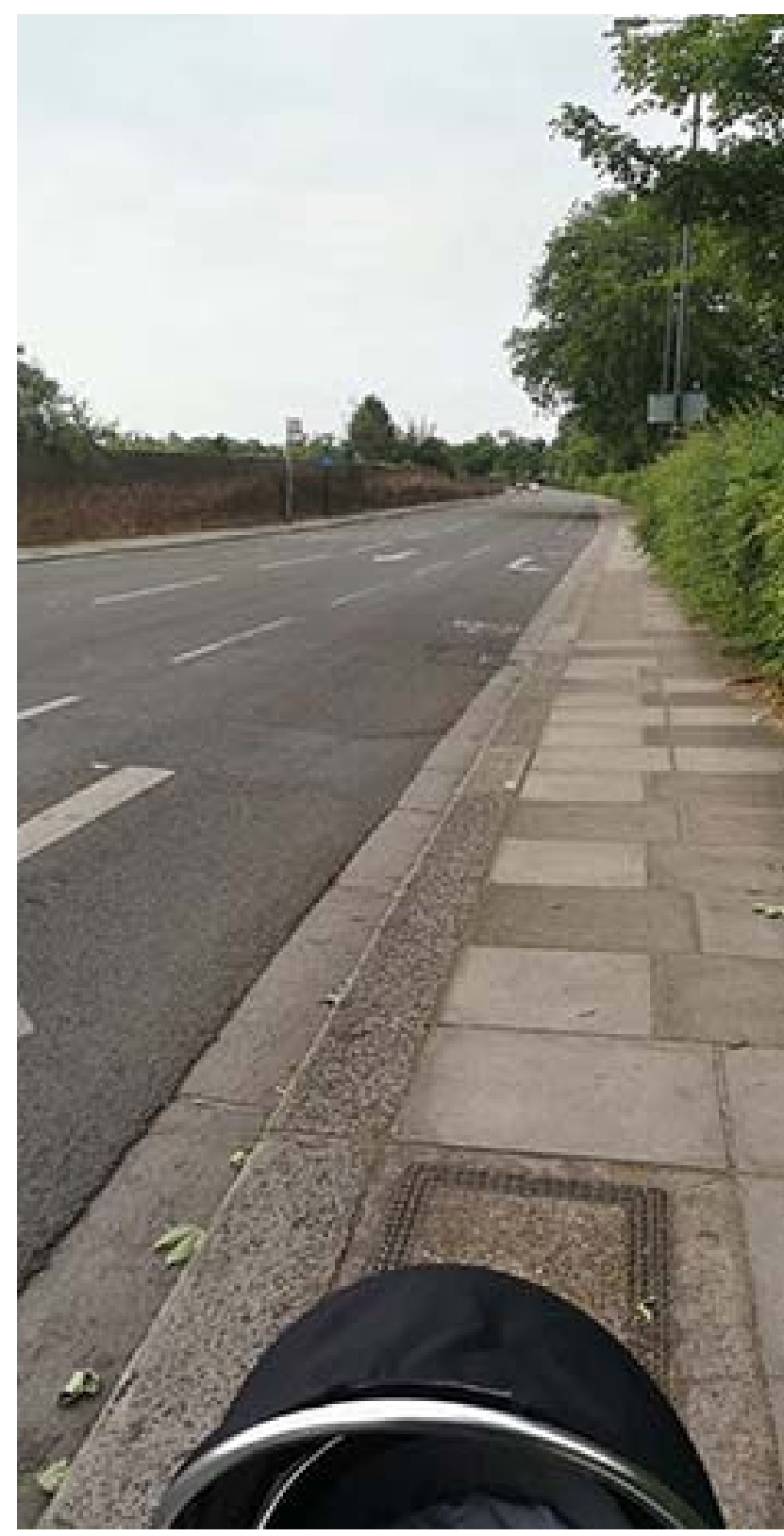

Figure 2. Travels with my pram. Photo courtesy of the author.

cotton-masked and plastic-gloved who drive past us in their cars on their own. Relief is locking the door to the porch. Like Michel Foucault's (1977) disciplined/ punished window-figures during plague times, we can see outside and can be seen from the outside, but nothing can come in and infect us - so long as we are meticulous about disinfecting the door handles, the post and shopping delivered. I watch the news on the computer and take my work breaks watching the news on the television. Eat. Try to sleep. Try not to repeat.
Life in the pandemic is both similar and different. Or it is similar but with a difference. Sometimes I catch myself with this Contagion ${ }^{1}$ coming out of the big screen. 'It's like living in a science fiction film' I hear repeated on the radio, and in the television news and with some of my academic colleagues still trying to write their histories from before when the world changed. Each morning I wake up with the shock of this new COVID condition. Our existentialities shaken, our democracies challenged, our intimacies restricted, we hold onto the routines and patterns of life, that labyrinth of lifeways that we call the everyday, the quotidian, or more potently the 'new normal'. One of these twisted new norms lies in the reconstitution of my tango fraternity online: from the Thursday nights in the church hall down in the nearby town now closed but re-opening I hear for 'individual prayer $^{\prime 2}$ - to a bi-weekly online Zoom class.

This omniscient scenario reminds me of my reactions to the Montserrat volcano crisis - a disaster in the Caribbean that is still ongoing (July 1995 to present). On the island, there was a period of denial, an insistence on maintaining the everyday state of affairs such as icing a wedding cake for the weekend with earthquake tremors, ashfall and the stench of sulphur shrouding the experience (Skinner 2016). It takes a while to become settled to the new resettled, to 'living with the unexpected', which Anja Possekel (1999) suggests is how the people of Montserrat live alongside the volcano, to developing a resilience to change and disaster, and now being able to regenerate and repackage the island as 'the green and the gritty'3 (Skinner 2015) rather than 'the way the Caribbean used to be'. ${ }^{4}$ In disasters, we lose our mental compasses, those cognitive 'mazeways' (Oliver-Smith 1986: 188) that give order and structure to our everyday and guide us rather like an internal tour guide. These are lost in the crisis and in what we hold onto. On Montserrat, the disaster became ontological as the landscape was ripped up; families, businesses and radio stations relocated increasingly north on the island time and time again; pyroclastic mudflows reshaping the surface of the south entirely. In times of COVID-19, the crisis is more covert: it can be resting on a surface, floating on a droplet, lurking in a skin fold. It can't be seen and so can be forgotten but for the 'in-your-face' reminders and warnings, the social distancing, the PPE that no longer refers just to an elitist degree pathway. Kirsten Bell (2020) deems this new safety clothing 'an apocalyptic fashion parade', ${ }^{5}$ more an example of contagious thinking than an illustration of our postmodern COVID-19 contagion. 
Now we have the exponential massification of illness sufferers, an intensification of flu symptoms, an acceleration of strains of symptoms. Within this new hyper Dark Age, I found solace in my socially distanced leisure pursuits. They bookend my working week as an academic. Tennis and Zoom tango - two of my regular hobbies from home - are both transferable into an acceptable everyday lockdown practice. First I was practising tennis shots from the car park of a closed gym with a ball on a string (Figure 3). Now we are socially distanced singles, each with our own tennis balls, changing on opposite sides of the court and leaving separately without small talk at the end. For introverts like me, I prefer it this way though there are eerie moments when I am the only person in an entire leisure complex and I can role play Duncan Bannatyne with his health clubs ${ }^{6}$ (Figure 4).

The other leisure pursuit, Argentine tango, is a dance I have wrestled with for a long time, as long as my relationship with my dance and life partner. I came to Zoom tango following the research angle as our intimacies transitioned online alongside the Zoomba variant on Zumba, and alongside online PT classes. I was surprised how much I started to need and miss the twice-weekly instalments with my isolating dance friends. This had been my pre-
COVID-19 normal for several years dancing and demonstrating with Freedom Tango ${ }^{7}<-$ there I am leading a dance in the top right of the hyperlink. This had been a part of my wellbeing before it became solitary pram walks with my unnamed son (we still can't register his birth and his names). This well of being, wellbeing, is expansively defined by Nigel Rapport (2009) as a Janus-faced retrospective and prospective narrative. It is the routines that we are accustomed to and the expectations we have for our abilities and capacities. It is informed by our pasts and achieved into our futures. It is a 'well-becoming' (2009: 202). There is thus a rhythm about these routines, one of work and leisure standing, or sitting rather, in contrast with each other, and wellbeing as a contrast with not being able to do these things. Wellbeing is thus harmony and balance between work and play, health and sickness, and is easily upset. It is fragile in its individuality and dependence upon others.

The Zoom tangoistas, like me, have faced a mandatory open-ended quarantine as the $\mathrm{R}$ numbers determine our fate. This is the new 'disciplinary mechanism' Foucault (1977: 197) identified in Medieval times and subsequently attached to the Enlightenment's ironic principle of self-surveillance: Jeremy Bentham's panopticon. The new syndics are my nosey neighbours
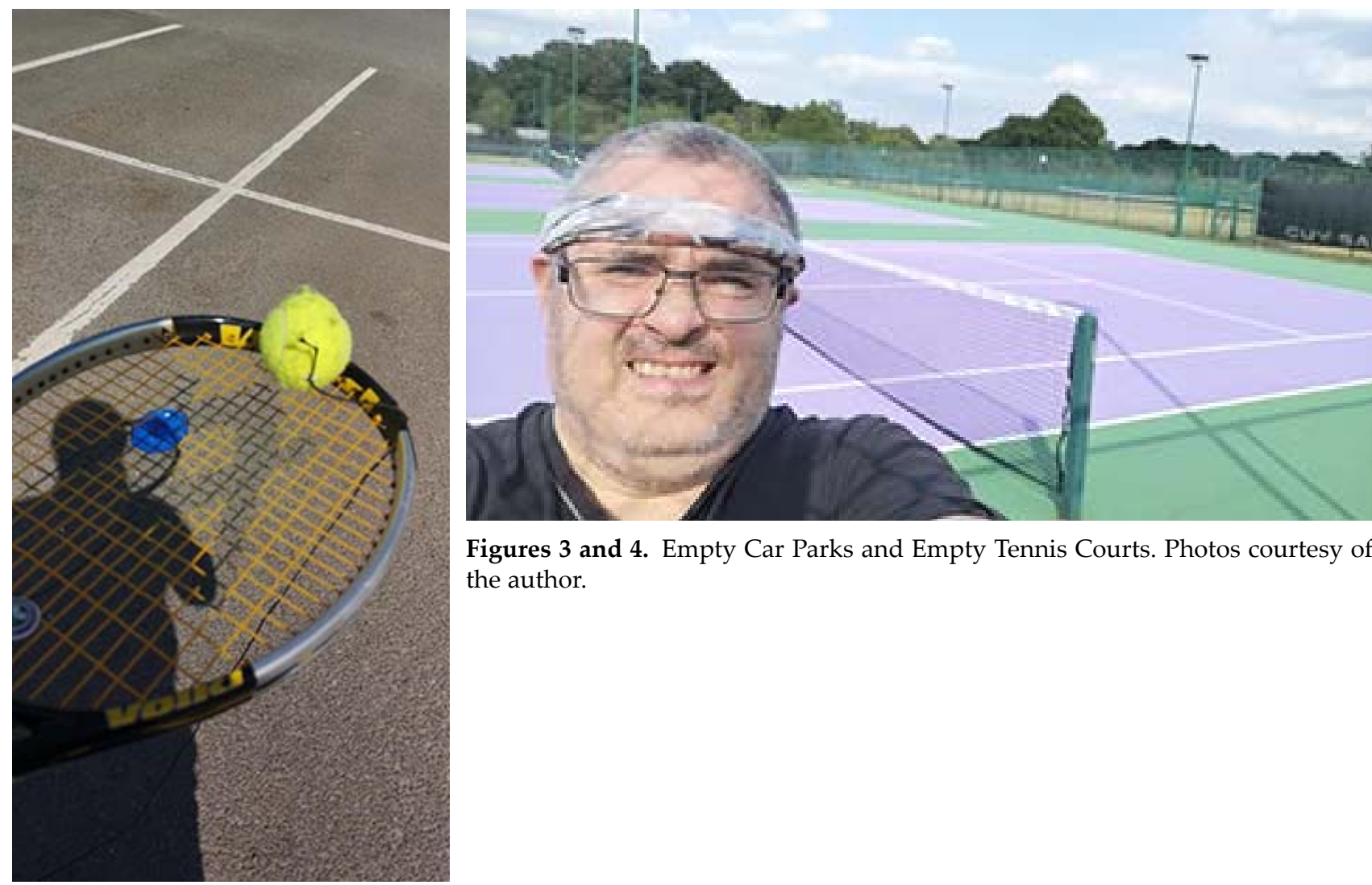

Figures 3 and 4. Empty Car Parks and Empty Tennis Courts. Photos courtesy of the author. 
taking a knee and clapping for our Modern healthcare system. These Zoom meetings reminded me of our dances together, their hold, their feel, the dance palpations with my fleeting partner. We steadied each other on the dance floor as we moved and rotated and drew complex patterns with our feet. Now their gaze back at me steadies my weekly lockdown resolve. And the dance class appointments structured my home-university academic diary. In synchronous fashion, we have continued our dance practices, readying ourselves for a new return to the dance floor. Yet tango, more than many dance forms, relies on an intimacy as the follower leans in close, as bodies combine axes at the sternum and as improvisation to the music takes us to new places. This makes it a dangerous dance unwittingly structured to facilitate the spread of infection. The lost embrace ${ }^{8}$ : the most virtual of arts alongside music has not survived the pandemic. Already the embrace is lost and tango in a time of coronavirus ${ }^{9}$ is under question.

The Argentine tango is safe on Zoom. It does not necessitate person-to-person contact, but then is it still a tango when the dance is characterised as 'call-and-response on the dance floor' by art historian Robert Thompson (2005: 6) tracing the African roots of this melancholic movement from Africa to Argentina to Europe? Virginia Gift's tango as 'silent conversation' (2008: 37) between dancers has had to be vocalised. Here we have a Zoom call through the mobile phone, tango on App as our maestro Juan Manuel Acosta switches up his person-to-person teaching to a computer-mediated group lesson with two poles (broomstick handles, golf clubs, garden canes in my case) to represent the two legs of our former dance partners. From there we built up a working knowledge of tango walking with our symbolic partners, crossing their legs as the leader, dissociating our torso to lead the intention. The tango embrace, that 'natural, loving hug' of dancers standing heart to heart (Denniston 2007: 31), was gaping, but I could sometimes see the other participants during the classes, especially when they chipped in with comments or questions or were instructed to add more of a movement during our practice or to collect our feet between steps. Each pole started off proportionally in front of our hips. We learnt how to control them as proper steps, to avoid slipping, to integrate their movement into our musicality and timing. ‘ßBailar! ¡Bailar!' came the friendly refrain. I was told that I danced better, more carefully, when I was cheek to cheek with Casian in my arms. Then, I stepped and transferred. I collected. I carried myself with care and intention. His weight also helped with the rotations, the giros around each other and cutting sacadas as I displace my poles or imaginary baby's legs, and the stuttering steps of the traspie rhythm (Figures 5, 6 and 7).

'Dance with the music. Catch the idea of the rhythm and also the body is more in control'. As the weeks went by and our Wednesday afternoon and Saturday evening classes progressed, we gained complexity in the routines and our teacher developed new teaching skills for Zoom. Demonstrations of moves had to be given from front, back and side perspectives, especially when the poles were crossed so that we could see which 'foot' goes where. Juan Manuel added videos of the week's moves on WhatsApp chats. This was eventually developed into an online classroom with clips, exercises and further explanation. This development was explained as a consequence of COVID-19: 'We are in a new system. No options. Make good this moment. Go deep in our creativity this time we are in', encouraged Juan Manuel.

This was sometimes needed as the lessons were broken up into 40-minute chunks and new calls had to be made. The poles took on a character of their own: they were described as 'slim', and as 'Margarita' after Margaret our Teddington teacher and Zoom moderator who was organising the classes for us. And the music became increasingly important: 'If the music is inside of us, you can do any sequence using the same beat'. It reached out of the social media to touch us, figuratively, and break our quarantine. We also learnt to listen out for our names when the teacher was leaning in observing our patterns; 'Jonathan, don't dance salsa', came some comments on the Zoom call as the teacher reminded me not to use my hips and to collect my feet when changing weight. We learnt how to front-light our phone and laptop cameras to get a clear view across our living rooms, bedrooms and kitchens where we were dancing, and we sneak-peeked which couple on the course to follow if we got lost and needed a local perspective on what the teacher was demonstrating with his poles their partner filled in and fleshed out the legs and feet for us. They also served as a reminder of what we were doing and why. This is all practice for when we can return to the in-person tango and the stranger's warm embrace.

In his The Story of the Embrace, tango historian Benzecry Sabá suggests that the tango embrace connects us back to some of the first stimulations we have as a baby cradled and hugged. The relief derived from this physical contact is palpable. He adds that the hugging stimulates oxytocin production in the 

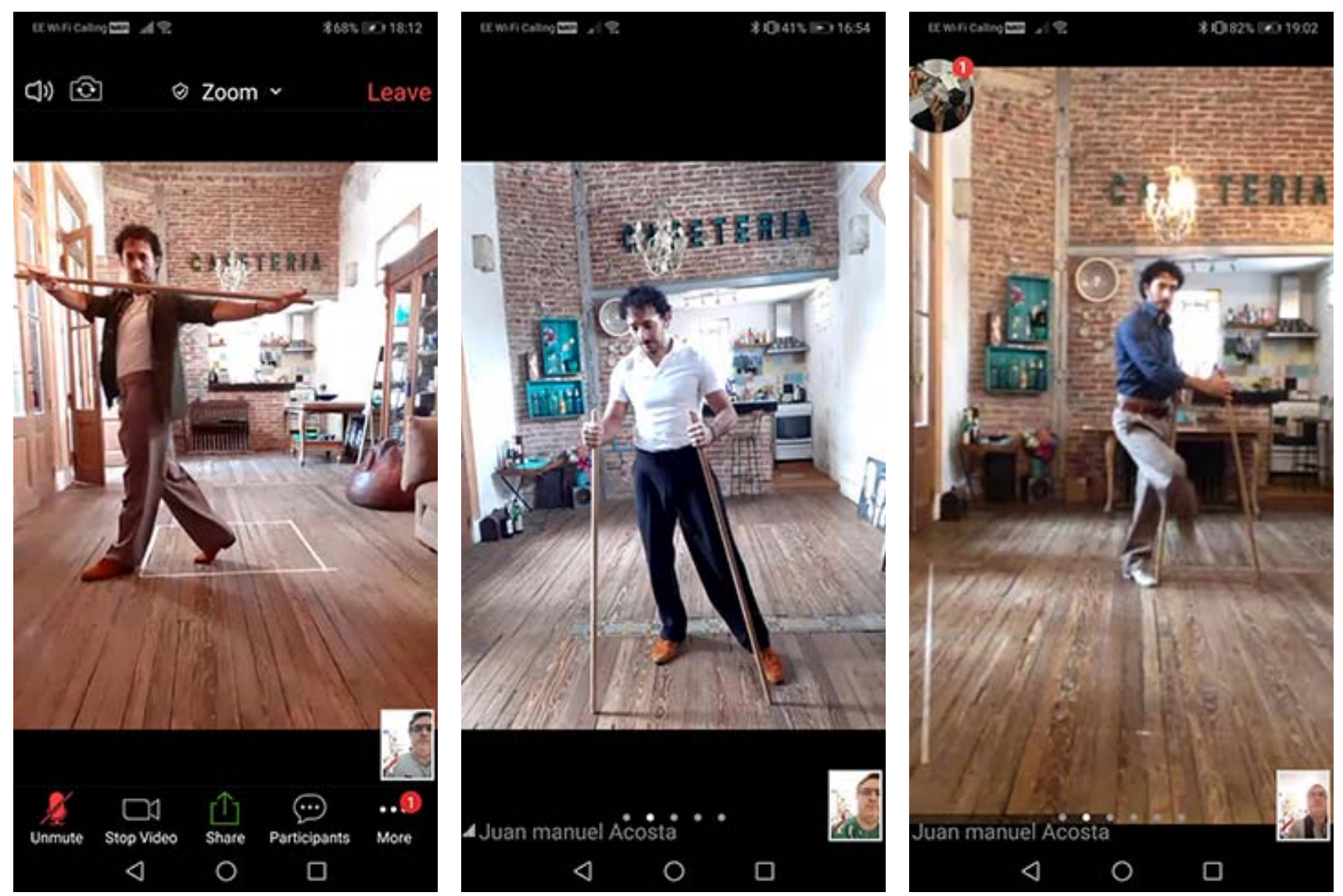

Figures 5, 6, 7. Juan Manuel Acosta demonstrating dissociation in the tango walk, dancing with poles, a gancho around the follower's right leg. Photos courtesy of the author (used with permission of Juan Manuel Acosta).

blood - the 'hormone of infatuation and motherhood' (2008: 35) - influencing sexual behaviour, affectivity and tenderness. Confined, as solo dancers, we are denied this human contact, this physical connectivity. This temporary condition leads to a 'skin hunger' (Anon. 2020), a sense-lessness equivalent to a malaise in this proprioceptive-lacking time of neuro-deprivation. More pertinently, even solo exercise in an elder population can enhance immuno-surveillance and reduce systemic inflammation (Son et al. 2020). Tim Edensor (2010) mentions how the rhythms internal and external to the body establish us in space and time. Our 'corporeal capacities' (2010: 5) are to read what is going on around us and inside us. This is our 'ontological security', Edensor proposes. Without these usual cues, our senses dull, our reactions slow, our capacities dwindle. For our autonomy, we need those moments of intimacy and a reflexivity borne from interaction with others. Zoom tango, tennis and my newborn son Casian are teaching me that.

Anthony Giddens writes that 'the possibility of intimacy means the promise of democracy' (1992:
188). Relationships between friends, lovers, parent- child, but also the more distant social and state actors, need to be open, tolerant and supportive of his reflexive project of the self. Violent, coercive, prohibitive, abusive relations at the different levels impinge, threaten and thwart what Giddens labels our 'life politics' (1992: 196). Giddens was writing about sexuality and sexual emancipation, but his work coincides with COVID-19, with how we respond with our 'civilising offensives' (Goodwin et al. 2020: 14) of washing and masking-up, social distancing and self-isolating ourselves both from and for the wider society. Digital, racial and structural inequalities slow down and counter this, and advantages and privileges assist this: witness Jacqueline Sanchez Taylor (2020) feeling her 'life interrupted' by COVID-19 just as it has been in the past along racial discrimination lines whilst taking yoga classes in rural Somerset; and Shola Richards' Facebook post ${ }^{10}$ that went viral when he pointed out that, as a successful Black man walking in his expensive neighbourhood, he still felt that he had to have his hand held by his daughter or 
to marshal his dog alongside him for fear of racist attack. Soon Casian will graduate from the Moses basket carrycot part of the pram - where his view is only of my face and the blue skies of Britain - to the pram seat itself. That view will be less intimate and undoubtedly a lot more problematic for him.

\section{Acknowledgements}

I would like to thank Juan Manuel Acosta, tango maestro, for his instruction, and for permission to carry out research and publish my findings. I would also like to thank Margaret Lochrie for her suggestions.

JonAthan SKInNer is Reader in Social Anthropology at the University of Roehampton with interests in leisure - specifically tourism and dance.

E-mail: jonathan.skinner@roehampton.ac.uk

\section{Notes}

1. https://www.imdb.com/title/tt1598778/

2. https://metro.co.uk/2020/06/07/places-worship-re open-june-15-private-prayer-12816308/

3. http://www.mnialive.com/articles/let-s-get-grit ty-on-the-black-and-green

4. https://www.islandrealestate.com/info/caribbean/ montserrat/

5. http://eportfolios.roehampton.ac.uk/anthroehamp ton/2020/04/06/its-a-kind-of-magic-coronavirus-at tire-mimesis-and-the-limits-of-rationalism1/

6. https://www.bannatyne.co.uk/health-club

7. http://www.freedomtango.co.uk/

8. https://news.yahoo.com/argentine-tango-dancerssolo-awaiting-embrace-lost-pandemic-061654724 .html

9. https://www.tangomarathons.com/2020/03/tan go-during-after-coronavirus-crisis/

10. https://www.facebook.com/shola.richards.7/pos ts/10163797079620220

\section{References}

Anon. (2020), ‘Hambre de piel: el fenómeno neurológico que explica por qué la falta de contacto físico en la pandemia de coronavirus también daña la salud' ('Skin hunger: The neurological phenomenon that explains why lack of physical contact in the coronavirus pandemic also damages health'), Infobae - Science America, 19 May, https://bit.ly/2GATjDy.
Bell, K. (2020), '“It's a Kind of Magic”: Coronavirus Attire, Mimesis and the Limits of Rationalism'. Anthroehampton Blog, 6 April, http://eportfolios .roehampton.ac.uk/anthroehampton/2020/04/06/ its-a-kind-of-magic-coronavirus-attire-mimesis-andthe-limits-of-rationalism1/.

Denniston, C. (2007), The Meaning of Tango: The Story of the Argentinean Dance (London: Portico).

Edensor, T. (2010), 'Introduction: Thinking about Rhythm and Space', in Geographies of Rhythm: Nature, Place, Mobilities and Bodies, (ed.) T. Edensor (London: Routledge), 1-20.

Foucault, M. (1977), Discipline and Punish (London: Penguin).

Giddens, A. (1992), The Transformation of Intimacy: Sexuality, Love and Eroticism in Modern Societies (Cambridge: Polity Press).

Gift, V. (2008), Tango: A History of Obsession (London: Amazon Books).

Goodwin, J., L. Parsons and H. O'Connor (2020), 'COVID-19: A Global "Civilising Offensive"', Timelines 129, 13-15, https://www.asanet.org/sites/de fault/files/history_-_issue_29_may_revision.pdf.

Oliver-Smith, A. (1986), The Martyred City: Death and Rebirth in the Andes (Albuquerque: University of New Mexico Press).

Possekel, A. (1999), Living with the Unexpected: Linking Disaster Recovery to Sustainable Development in Montserrat (Cham, Switzerland: Springer).

Rapport, N. (2009), Of Orderlies and Men: Hospital Porters Achieving Wellness at Work (Durham, NC: Carolina Academic Press).

Sabá, S. (2008), La Pista Del Abrazo: Técnicas y Metáforas entre el Tango y la Vida [The story of the embrace: Techniques and metaphors between the tango and life] (Stuttgart: Abrazos Books).

Skinner, J. (2015), 'Let's Get Gritty on the Black and Green', MNIalive.com - Global Caribbean Media, 21 May, http://www.mnialive.com/articles/let-sget-gritty-on-the-black-and-green.

Skinner, J. (2016), 'High Drama in the Anthropology of Risk', in Honors Committee UNIAPAC Foundation Board Think Tank Meeting: 'Risk as Source of Life', (ed.) P. Lecocq (Paris: Fonds De Dotation UNIAPAC), 12-23.

Son, J., G. Nimrod, S. West, M. Janke, T. Liechty and J. Naar (2020), 'Promoting Older Adults' Physical Activity and Social Well-Being during COVID-19', Leisure Sciences, doi:10.1080/01490400.2020.1774015.

Taylor, J. (2020), 'Life Interrupted: COVID-19 and Black Lives Matter', Discover Society, 25 June, https://discoversociety.org/2020/06/25/lifeinterrupted-covid-19-and-black-lives-matter/. Thompson, R. (2005), Tango: The Art History of Love (New York: Vintage Books). 